\title{
Draft Genome Sequence of Agrobacterium deltaense Strain CNPSo 3391, Isolated from a Soybean Nodule in Mozambique
} \author{
Stephen Kyei-Boahen, ${ }^{d}$ Marco Antonio Nogueira, ${ }^{a, c}$ (D) Mariangela Hungriaa,b,c \\ aEmbrapa Soja, Soil Biotechnology Laboratory, Londrina, Paraná, Brazil \\ bDepartment of Microbiology, Universidade Estadual de Londrina, Londrina, Paraná, Brazil \\ 'CNPq, SHIS QI 1 Conjunto B, Blocos A, B, C e D, Lago Sul, Brasília, Federal District, Brazil \\ dInternational Institute of Tropical Agriculture (IITA), Nampula, Mozambique
}

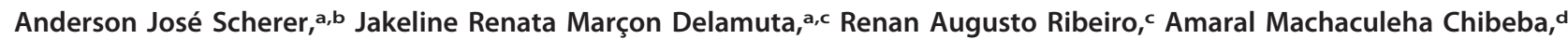

ABSTRACT Agrobacterium deltaense strain CNPSo 3391 was isolated from a soybean nodule in Mozambique. Its genome size was estimated at 4,926,588 bp. This isolate carries several coding sequences for stress tolerance, but no identifiable nodulation or virulence genes. Possible ecological roles of bacteria isolated from legume nodules and closely related to Agrobacterium are discussed.

Fingen or 2 decades our group has reported the isolation of agrobacteria from root nodules of soybean (Glycine max) (1-3), common bean (Phaseolus vulgaris) (4-6), and other legumes (7-9). However, the ability to reestablish nodulation with the host legume is usually not confirmed. Another example is the Agrobacterium deltaense type strain YIC4121, isolated from a root nodule of Sesbania cannabina in China; the ability to nodulate seven legumes was not confirmed (10). Here, we report the draft genome sequence of strain CNPSo 3391 (= Moz59, = $9 \mathrm{J1}$ ), isolated from a plant grown in Mutequelesse, Gurué District, Zambézia Province, Mozambique, showing no symptoms of $\mathrm{N}$ deficiency. Preliminary genetic characterization based on the $16 \mathrm{~S}$ rRNA and three housekeeping genes positioned the strain in a Rhizobium (Agrobacterium) clade (3).

Growth conditions for CNPSo 3391 were the same as those reported for its isolation (3), and DNA extraction and paired-end sequencing on the MiSeq platform (Illumina) were performed as described before (11), resulting in 630,975,648 bp. Shotgun sequences were assembled with the A5-MiSeq pipeline (de novo) v.20140604 with 128 -fold genome coverage assembled in 50 contigs with an $N_{50}$ of $177,127 \mathrm{bp}$. The genome was estimated at 4,926,588 bp, with $\mathrm{G}+\mathrm{C}$ content of 59.9 mol\%, confirmed with RAST v.2.0 (12) and QUAST v.2.0 (13), using default parameters. Average nucleotide identity (ANI) (ANI calculator [14]) indicated highest similarity (97.68\%) with Agrobacterium deltaense $\mathrm{YIC} 4121^{\mathrm{T}}$. Compared to the genomes of $A$. deltaense at the NCBI (strains NCPPB 1641, RV3, Zutra 3-1, and YIC4121 ${ }^{\mathrm{T}}$ ), CNPSo 3391 is slightly smaller than YIC4121 $1^{\top}(5.02 \mathrm{Mb})$, but within the same $\mathrm{G}+\mathrm{C}$ range of all strains.

A total of 4,765 DNA coding sequences (CDSs) were identified in RAST (12), with 49\% classified in 475 subsystems; this annotation is the public version available at GenBank. Similarly to A. deltaense YIC4121 ${ }^{\top}$, CNPSo 3391 carries no nodulation genes or nif and fix operons. However, CNPSo 3391 also carries no genes related to virulence, and we were not able to find sequences coding for telA, related to the speciation of some Agrobacterium (15). The environmental adaptability of CNPSo 3391 might be explained by genes such as 63 CDSs related to resistance to antibiotic and toxic compounds, 51 to iron acquisition and metabolism, 104 to motility and chemotaxis, and 162 to stress response.

Isolation of agrobacteria from legume root nodules seems to occur worldwide, with

Citation Scherer AJ, Delamuta JRM, Ribeiro RA, Chibeba AM, Kyei-Boahen S, Nogueira MA, Hungria M. 2019. Draft genome sequence of Agrobacterium deltaense strain CNPSo 3391, isolated from a soybean nodule in Mozambique. Microbiol Resour Announc 8:e01675-18. https://doi.org/10.1128/MRA .01675-18.

Editor David A. Baltrus, University of Arizona Copyright $\odot 2019$ Scherer et al. This is an open-access article distributed under the terms of the Creative Commons Attribution 4.0 International license.

Address correspondence to Mariangela Hungria, mariangela.hungria@embrapa.br. Received 11 December 2018 Accepted 5 February 2019 Published 7 March 2019 
reports in Brazil (2, 4, 6-9), China (10), Ecuador (5), Mozambique (3), and Paraguay (1), among other countries. As these bacteria apparently do not carry nodulation genes, Yan et al. (10) suggested that they might be endophytes, but we cannot discard the hypothesis of a temporary acquisition of a symbiotic plasmid from another rhizobia. However, the role of agrobacteria in symbiosis deserves further investigation; interestingly, 3 decades ago in vivo results suggested that Agrobacterium spp. might produce extracellular "signals" that would supplement the ability of rhizobia to induce root nodulation in the host legume (16).

Data availability. This whole-genome shotgun project has been deposited at DDBJ/ EMBL/GenBank under the GenBank accession number RRZI00000000, BioProject number PRJNA507793, BioSample number SAMN10506010, and organism number RRZI00000000; the version described in this paper is RRZI01000000.

\section{ACKNOWLEDGMENTS}

Funding was provided by Embrapa, INCT-Plant Growth-Promoting Microorganisms for Agricultural Sustainability and Environmental Responsibility (CNPq 465133/2014-2, Fundação Araucária-STI, CAPES), CNPq-Universal (400468/2016-6), and Coordenação de Aperfeiçoamento de Pessoal de Nível Superior-Brasil (CAPES, Código de Financiamento 001).

\section{REFERENCES}

1. Chen LS, Figueredo A, Pedrosa FO, Hungria M. 2000. Genetic characterization of soybean rhizobia in Paraguay. Appl Environ Microbiol 66: 5099-5103. https://doi.org/10.1128/AEM.66.11.5099-5103.2000.

2. Hungria M, Chueire LMO, Megías M, Lamrabet $Y$, Probanza A, GuttierrezMañero FJ, Campo RJ. 2006. Genetic diversity of indigenous tropical fast-growing rhizobia isolated from soybean nodules. Plant Soil 288: 343-356. https://doi.org/10.1007/s11104-006-9125-0.

3. Chibeba AM, Kyei-Boahen S, Guimarães MF, Nogueira MA, Hungria M. 2017. Isolation, characterization and selection of indigenous Bradyrhizobium strains with outstanding symbiotic performance to increase soybean yields in Mozambique. Agric Ecosyst Environ 246:291-305. https:// doi.org/10.1016/j.agee.2017.06.017.

4. Grange L, Hungria M. 2004. Genetic diversity of indigenous common bean (Phaseolus vulgaris) rhizobia in two Brazilian ecosystems. Soil Biol Biochem 36:1389-1398. https://doi.org/10.1016/j.soilbio.2004.03.005.

5. Ribeiro RA, Ormeño-Orrillo E, Dall'Agnol RF, Graham PH, MartinezRomero E, Hungria M. 2013. Novel Rhizobium lineages isolated from root nodules of common bean (Phaseolus vulgaris L.) in Andean and Mesoamerican areas. Res Microbiol 164:740-748. https://doi.org/10.1016/j .resmic.2013.05.002.

6. Costa MR, Chibeba AM, Mercante FM, Hungria M. 2018. Polyphasic characterization of rhizobia microsymbionts of common bean [Phaseolus vulgaris (L.)] isolated in Mato Grosso do Sul, a hotspot of Brazilian biodiversity. Symbiosis 76:163-176. https://doi.org/10.1007/s13199-018 -0543-6.

7. Menna P, Hungria M, Barcellos FG, Bangel EV, Hess PN, Martínez-Romero E. 2006. Molecular phylogeny based on the 16S rRNA gene of elite rhizobial strains used in Brazilian commercial inoculants. Syst Appl Microbiol 29: 315-332. https://doi.org/10.1016/j.syapm.2005.12.002.

8. Binde DR, Menna P, Bangel EV, Barcellos FG, Hungria M. 2009. rep-PCR fingerprinting and taxonomy based on the sequencing of the 16S rRNA gene of fifty-four elite commercial rhizobial strains. Appl Microbiol Biotechnol 83:897-908. https://doi.org/10.1007/s00253-009-1927-6.

9. Roma Neto I, Ribeiro RA, Hungria M. 2010. Genetic diversity of elite rhizobial strains of subtropical and tropical legumes based on the $16 \mathrm{~S}$
rRNA and glnll genes. World J Microbiol Biotechnol 22:1291-1302. https://doi.org/10.1007/s11274-009-0300-3.

10. Yan J, Li Y, Han XZ, Chen WF, Zou WX, Xie Z, Li M. 2017. Agrobacterium deltaense sp. nov., an endophytic bacteria isolated from nodule of Sesbania cannabina. Arch Microbiol 199:1003-1009. https://doi.org/10 .1007/s00203-017-1367-0.

11. Megías $E$, Reis Junior FB, Ribeiro RA, Ollero FJ, Megías M, Hungria $M$. 2017. Genome sequence of Pantoea ananatis strain AMG 501, a plantgrowth promoting bacterium isolated from rice leaves grown in paddies of southern Spain. Genome Announc 5:e00848-17. https://doi.org/10 .1128/genomeA.00848-17.

12. Aziz RK, Bartels D, Best AA, DeJongh M, Disz T, Edwards RA, Formsma K, Gerdes S, Glass EM, Kubal M, Meyer F, Olsen GJ, Olson R, Osterman AL, Overbeek RA, McNeil LK, Paarmann D, Paczian T, Parrello B, Pusch GD, Reich C, Stevens R, Vassieva O, Vonstein V, Wilke A, Zagnitko O. 2008. The RAST server: Rapid Annotations using Subsystems Technology. BMC Genomics 9:75. https://doi.org/10.1186/1471-2164-9-75.

13. Gurevich A, Saveliev V, Vyahhi N, Tesler G. 2013. QUAST: quality assessment tool for genome assemblies. Bioinformatics 29:1072-1075. https:// doi.org/10.1093/bioinformatics/btt086.

14. Rodriguez-R LM, Konstantinidis KT. 2016. The enveomics collection: a toolbox for specialized analyses of microbial genomes and metagenomes. PeerJ Prepr 4:e1900v1. https://doi.org/10.7287/peerj.preprints .1900v1.

15. Ramírez-Bahena MH, Vial L, Lassalle F, Diel B, Chapulliot D, Daubin V, Nesme X, Muller D. 2014. Single acquisition of protelomerase gave rise to speciation of a large and diverse clade within the Agrobacterium/ Rhizobium supercluster characterized by the presence of a linear chromid. Mol Phylogenet Evol 73:202-207. https://doi.org/10.1016/j.ympev .2014.01.005.

16. Caetano-Anollés G, Bauer WD. 1988. Enhanced nodule initiation on alfalfa by wild-type Rhizobium meliloti co-inoculated with nod gene mutants and other bacteria. Planta 174:385-395. https://doi.org/10 .1007/BF00959525. 